\title{
Demographic Factors and Its Influence on Job Satisfaction in Adamawa State University, Mubi
}

\author{
Sanusi Bello ${ }^{1}$, Mohammed Nasiru ${ }^{2}$ \\ ${ }^{1}$ Associate Professor, Department of Business Administration, Adamawa State University, Mubi-Nigeria \\ ${ }^{2}$ M.Sc. in View, Department of Business Administration, Adamawa State University, Mubi-Nigeria
}

Corresponding Author: Sanusi Bello

\begin{abstract}
This study identified the rationale that prompted the problems on how workers' satisfaction can help eliminate and reduce the problems that led to the complains made by students and other stakeholders. The major objective of the study is to examine the influence of demographic factors on job satisfaction of workers in Adamawa State University, Mubi. The total population of the study is eight hundred and twenty four (824) which comprises of two hundred and thirty two Academic Staff (232) and five hundred and ninety two (592) non academic Staff of different carders, the sample size for this study is 269 . The instrument used for collecting data from the respondents is the questionnaire, and the data collected from the respondents was analyzed using percentage analysis. The regression analysis shows that the $\mathrm{t}-$ statistics is negative and positively signed $(\mathrm{r}=-12.846,-\beta=0.243$, $0.085 \&-13.818, \mathrm{P}<0.05)$. Also the findings revealed that staffs are not satisfied with the content quality of their responsibility. The study therefore, recommends that management should be give due consideration when dealing with staff in a flexible ways not rigid, the management should also provide adequate technical support needed to carry out their duties diligently.
\end{abstract}

Keywords: Demographic, factors, influence, job $\&$ satisfaction

\section{INTRODUCTION}

Job satisfaction is the extent to which people like (satisfaction) or dislike (dissatisfaction) their jobs; while according to Armstrong (2006), job satisfaction refers to the attitudes and feelings people have about their work. Managers and researchers aim at identifying job satisfaction determinants in order to develop appropriate strategies that can help optimize employee productivity.

Several studies have been made to assess factors influencing job satisfaction at workplaces. Some researchers have concluded that job satisfaction is more of a function of intrinsic factors than extrinsic factors (Beyene \& Gituma, 2017). On the other hand, researchers such as Igalens and Roussel (1999) and Brewer, Lim and Cross (2008) have conclude that job satisfaction is more of a function of extrinsic factors than intrinsic factors while Beyene and Gituma (2017) observed that both intrinsic and extrinsic factors played a great role on job satisfaction.

DeVaney and Chen (2003), showed that demographic variables such as age, gender, race, and education have an effect on job satisfaction. Malik (2011) found that demographic variables, age, job rank, job qualification and years of experience were slightly related to the overall job satisfaction of university faculty members. Relationship between faculty job satisfaction and demographic variables of faculty members in a public higher education in Singapore, Paul and Phua (2011) indicated that while variables such as job position and age influenced the levels of job satisfaction, the variables: academic qualification, gender, marital status, and length of employment had no influence of statistical significance. 

Mubi.

But demographic factors such as; current job status, marital status, age and salary appear to have significant impact on the respondents' level of job satisfaction.

Ward and Sloane (2000) argued that gender had no any statistical significance in terms of overall job satisfaction with reference of certain extant studies. However, Bender and Heywoo (2006) indicate that female faculty experience lower job satisfaction than male among faculty members. On the other hand, Santhapparaj and Alam (2005) found that female academic staff members are more satisfied than their male equivalents. According to Mehboob, Sarwar, and Bhutto (2012), female faculty members were more satisfied with their jobs than their male counterparts at the university. And also Castillo and Cano (2004) found that compared to male faculty members, female academic staff members were lesser satisfied. Similarly, findings of Moguerou (2002) also concluded that female members are less satisfied than male members. Syed et al. (2012) found that female faculty members are more satisfied compared with male faculty member. Crossman and Harris (2006) reported that males were slightly more satisfied than females.

Crossman and Harris (2006) explained age has been associated with job satisfaction, but the nature of the relationship is not clear. Oshagbemi (2003), found age is not significantly related to job satisfaction. However, research findings have indicated that the job satisfaction of university faculty members from Uganda reported age to be a significant influence on teaching satisfaction (Ssesanga \& Garrett, 2005). According to DeVaney and Chen (2003) older workers are more likely to be satisfied than younger workers. Similarly studies have it that job satisfaction increases with age.

As demographic variable, extant research indicates that marital status has an influence on satisfaction of faculty members, but has inconsistent evidence (Sabharwal \& Corley, 2009). However, empirical findings depict that marriage positively influences the satisfaction level of academic staff members (Cetin, 2006). Consistent with the finding, Hagedorn (2000), said marriage has increased job satisfaction levels of university faculty members. According to the Oshagbemi (2003), marital status is not significantly related to job satisfaction.

Sabharwal and Corley (2009) identified Current Working Status (i.e., Rank) was a significant factor with additional control variables for faculty job satisfaction. Contrary to these findings, in a research performed in Northern Cyprus, Eyupoglu and Saner (2009) found no evidence that the degree of job satisfaction is increased by the academic rank of staff members. Findings of (Oshagbemi, 2003) conclude that job satisfactions of employees with higher ranks are higher than employees with lower ranks. Job satisfaction increases with a faculty member's rank (Hickson \& Oshagbemi, 1999). Furthermore, Oshagbemi (2003) concluded that the ranks of the academic faculty members are highly positively correlated with their overall job satisfaction. To the contrary, the findings of him further depicted that the length of service, gender and age of faculty members did not have significant relationships with the overall job satisfaction. Furthermore, in the findings of Gurbuz (2007), it was indicated that job satisfactions is positively influenced by job qualifications.

Tertiary institutions, like many other industries in Nigeria became vigorously involved in accelerating the wheels of economic and industrial development of Nigerian economy. The institution became actively involved in creating a link between the less educated and those who are willing to better themselves in terms of academic development in order to save those parts that leverage on the development of others. This can only be achieved when the employees are well satisfied with their job.

The distinction of individual employment characteristics may influence how employees feel about their work 
environment and the relationship between employee satisfaction and demographic factors may not be easily perceptible due to the fact that it is reconcile by their performance. Most employees of tertiary institutions in Nigeria have been yearning for increment in their salary and other working condition which makes the renowned Academic Staff Union of Universities (ASUU) to have recorded series of strike action in order to improve on the working condition of staff which was in an effort to improve their job satisfaction. However, despite the series of researches conducted in order to enhance job satisfaction, none was able to looked at the influence of demographic factors such as age, gender, marital status, and educational background have on employees job satisfaction in such tertiary institutions, especially, Adamawa State University, Mubi. Therefore, this study was motivated by the intent to examining the influence of demographic factors on job satisfaction of workers in Adamawa State University, Mubi through the identification of the rationale that prompted the aforementioned problems and how workers satisfaction can help eliminate and reduce the problems that led to the complains made by students and other stakeholders.

The following hypothesis is formulated to guide the study;

Ho: Demographic factors (age, gender, educational background, marital status) do not have significant effect on job satisfaction.

$\mathbf{H}_{1}$ : Demographic factors (age, gender, educational background, marital status) have significant effect on job satisfaction.

\section{LITERATURE REVIEW Concept of Demographic Factors}

Demographics is the study of general and particular population factors such as race, gender or occupation, as well as population density, size and location (Blythe, 2005). Demographics are the quantification of statistics for a given population and are used to identify the study of quantifiable sub-sets within a given population (Amangala, 2013). Demographic characteristics are widely used variables, in relation to organizational commitment and, as is shown in literature, there is a significant role of demographic factors in determining organizational commitment. Demographic factors such as age, gender, marital status, education and job tenure are included in many studies of the impact of demographic factors on commitment.

\section{Job Satisfaction}

Job satisfaction is one of the most complex area facing today's managers when managing their employees (Aziri, 2011). According to the Lise and Timothy (2004); employee surveys, can be used effectively for improving employee attitudes and making organizational changes. Warsi, et al (2009) found that job satisfaction, work motivation and organizational commitment were positively correlated each other. Job dissatisfaction also appears to be related to other withdrawal behaviours, including lateness; unionization, grievances, and drug abuse, and decision to retire (Lise \& Timothy, 2004).

Job satisfaction is a general attitude which is determined by the factors of job satisfaction (such as, pay, work, superior's attitude, environment etc.); personal characteristics of the worker (demographics); and social or group factors (Shajahan and Shajahan, 2004). People working in the private or government organization have certain needs to satisfy, which must be understood by the human resource management of the respective organization like university (Malik, Nawab, Naeem \& Danish, 2010).

It is a general attitude which is determined by the job predictors (i.e. pay, job, superior behavior and environment etc.) and the personal attitude (demographics) and other social and group factors (Shajahan and Shajahan, 2004). People working in the private or government organization bring with them certain needs that affect their performance therefore, understanding how 
these needs are related with performance and how rewards can lead to job-satisfaction are the urgent issues for every organization working at any level (Sattar et al., 2010; Malik et al., 2010).

\section{Impact of Demographic Factors on Job Satisfaction}

The research done by Jaime \& Jamie (2004) has investigated that demographic characteristics of faculty members were negligibly related to overall job satisfaction. Cano and Miller (1992) also found that the teacher's age, years in teaching and degree status were not significantly affected on their job satisfaction. If it was so; the research findings of Bas and Ardicin in (2002) on age and job satisfaction proved the positive correlation with each other. As said by Yunki (1999) sex was the most important demographic variable in relation to job satisfaction. The study done using 5000 British employees by Andrew (1996) found that job satisfaction was higher for women, older workers and those with lower level of education. According to Gurbuz (2007), level of education of four and five star hotel workers were positively related to their job satisfaction. Meagan et.al (2005) observed the significant relationship between demographic factors of gender and race with job satisfaction of extension agents. According to the findings of Berns in 1989; teacher's job satisfaction was increased with their age and level of education. McNeely (1984) and Miaris (1996) observed higher satisfaction level in female than male. However, Soleman (2005) and Collins and Helen (2013) did not found any significant difference of job satisfaction based on gender differences. In contrast to above results; Olorunsola (2010) found that male administrative officers were more satisfied than female administrative officers in Nigeria universities.

Several studies have explored the demographic attributes by using them as predictors of organizational attitudes, for example, gender, sector, designation, marital status, age, qualification, and experience (Saiyadain, 1998; Naval and Srivastava, 2004). The catalyst role of employee's personal attributes and demographic characteristics is recorded by almost every researcher on job satisfaction. Almost all the researchers have identified 'demographics' as the change agents, which modify employee's attitude towards different aspects of his/her job (Bas and Ardic, 2002; DeVane and Sandy, 2003). Demographics also affect workers attitudes in terms of productivity, involvement and commitment on one hand and on the other hand the degrees of absenteeism and turnover or intention to leave (Shamil and Jalees, 2004). Another group of researchers have recorded that age, gender, experience, department, foreign qualification or exposure to different culture, and technological challenges always influence the overall satisfaction of the employees (Tella, Ayeni, and Popoola, 2007; Asadi, et al., 2008; Sattar et al., 2010; Malik et al., 2010).

\section{Demographic Factors Affecting Job Satisfaction}

DeVaney and Chen (2003), showed that demographic variables such as age, gender, race, and education have an effect on job satisfaction. Malik (2011) found that demographic variables, age, job rank, job qualification and years of experience were slightly related to the overall job satisfaction of university faculty members. Relationship between faculty job satisfaction and demographic variables of faculty members in a public higher education in Singapore, Paul and Phua (2011), indicated that while variables such as job position and age influenced the levels of job satisfaction, the variables: academic qualification, gender, marital status, and length of employment had no influence of statistical significance. Noordin and Jusoff (2009), found that the demographic factors such as; current job status, marital status, age and salary appear to have significant impact on the respondents' level of job satisfaction. 

Mubi.

Ward and Sloane (2000), argued that gender had no any statistical significance in terms of overall job satisfaction with reference of certain extant studies. Similarly Sseganga and Garrett (2005), conducted research in Uganda and found that gender has no influence on job satisfaction of university faculty members. However, Bender and Heywoo (2006) indicate that female faculty experience lower job satisfaction than male among faculty members. On the other hand, Santhapparaj and Alam (2005) found that female academic staff members are more satisfied than their male equivalents. Malik (2011) highlighted 120 faculty members regarding their job satisfaction; he suggested that the level of job satisfaction among males was much less compared to that of female faculty members.

Noordin and Jusoff (2009) found that two hundred and thirty-seven of academics from a public university in Malaysia that in overall the academic staff of the university have a moderate level of job satisfaction. However, it is observed that there are only few studies conducted in the area of job satisfaction in the university education system in Nigeria. Therefore, the findings this research will contribute to fill in the gap in the local literature in Nigeria as well as developing countries in the region.

\section{Theoretical Framework \\ Content theories}

Content theories focus on identifying the needs, drives and goals that make an individual get satisfaction (Luthans, 2005). Some of the theories in this category are: Maslow's theory of 'Hierarchy of Needs' (Maslow, 1943); Herzberg's Two-Factor Theory; Achievement Theory (McClelland, 1961) and ERG Theory which regroups Maslow's list of needs into three classes of needs namely: Existence, Relatedness, and Growth (Alderfer, 1969). Many of the content theories premise that unsatisfied needs lead to unstable situations.

\section{Maslow theory on Hierarchy of Needs}

Maslow theory is a popular and attractive theory in the contemporary world. According to Maslow (1943), people seek to satisfy five basic needs which exist in a hierarchy whereby a person gradually graduates from one level to the next. The five basic needs are; physiological needs, safety needs, social needs, esteem needs and self-actualization needs. Maslow theory posits that once the needs at one level are satisfied, it ceases to motivate and the desire shifts to the next level (Dick, 2001). The lower needs are most salient until satisfied, at which point the next higher needs come into play. It is inferred from Maslow's theory that employees' need their lower level needs fulfilled before they are inspired by the higher level needs. Managers and leaders must therefore appreciate that workers have different needs which must be met to enable them perform at the higher level for the organization's success. Unsatisfied needs influence behaviour. Lower needs such as adequate pay and family must be met before focusing on high level needs (Jones and George, 2009).

\section{Herzberg's Two-Factor Theory}

Herzberg theory posits that there are two factors which lead people to either satisfaction or dissatisfaction with their work. Herzberg et al (1959) argued that the factors which cause satisfaction are totally different from those which cause dissatisfaction. Employee satisfaction depends on two sets of issues: "hygiene" issues and motivators. Hygiene factors include company policies, supervision, salary, security, status, interpersonal relations and working conditions. Hygiene issues cannot motivate employees but can cause dissatisfaction. Motivators are issues such as achievement, recognition, the work itself, responsibility and advancement. Motivators create satisfaction by fulfilling individuals' needs for meaning and personal growth. When hygiene areas are addressed, motivators will promote job satisfaction and encourage production. Once hygiene factors 

Mubi.

are fulfilled, the workers unhappiness and poor job performance is avoided. However, high happiness and high job performance would never be achieved unless motivators are provided. On the other hand, if workers have the motivators they would display high performance and satisfaction with their job even if the hygiene needs were not gratified (Worrell, 2004).

In view of the theories reviewed above, this study in is alignment with the content theory especially the Abraham Maslow's theory where emphasis was on how employees derive satisfaction in their job as they accelerate the ladder of attaining the height of their carrier. Given the nature of the case study under consideration, the employees' level of satisfaction is predetermined by their level of accomplishment of one needs while they look up to the other needs along the hierarchy portrayed by the hierarchy of needs as given by Maslow.

\section{METHODOLOGY}

The study adopted survey research design, the population comprises both Academic and non Academic Staff of Adamawa State University Mubi. The total population of the study is seven hundred and sixty eight (768) which comprises of two hundred and fifty nine Staff (259) and four hundred and sixty seven (467) non academic Staff of different carders. Therefore, the sample size for this study is 263; Yamani (1964) formula was used to draw the sample size for the study. The study adopted the closed-ended type of questionnaires. The questionnaires were designed on five point Likert scale ranging from strongly agreed (5) to strongly disagreed (1). While the hypotheses are tested using regression analysis at 0.05 level of significance.

\section{DATA PRESENTATION, ANALYSIS AND RESULTS}

Out of 263 questionnaires distributed;

Returned $\frac{261}{263} \times 100=99.2 \%$

Unreturned $\frac{2}{263} \times 100=0.8 \%$

261 were successfully returned and valid, representing $99.2 \%$, while 2 were not returned, representing $0.8 \%$

\section{Hypothesis Testing Regression}

\begin{tabular}{|l|l|l|l|l|l|}
\hline \multicolumn{5}{|c|}{ Model Summary $^{\mathbf{b}}$} \\
\hline Model & R & R Square & Adjusted R Square & Std. Error of the Estimate & Durbin-Watson \\
\hline 1 & $.919^{\text {a }}$ & .844 & .841 & 5.49947 & .271 \\
\hline \multicolumn{2}{|l|}{ Predictors: (Constant), marital status, education background, age, gender } \\
\hline \multicolumn{6}{|l}{ b. Dependent Variable: job satisfaction } \\
\hline
\end{tabular}

\begin{tabular}{|c|c|c|c|c|c|c|}
\hline \multicolumn{7}{|c|}{ ANOVA $^{b}$} \\
\hline \multicolumn{2}{|c|}{ Model } & Sum of Squares & Df & Mean Square & $\mathbf{F}$ & Sig. \\
\hline \multirow[t]{3}{*}{1} & Regression & 42478.492 & 4 & 10619.623 & 351.129 & $.000^{\mathrm{a}}$ \\
\hline & Residual & 7863.493 & 260 & 30.244 & & \\
\hline & Total & 50341.985 & 261 & & & \\
\hline \multicolumn{7}{|c|}{ a. Predictors: (Constant), marital status, educational background, age, gender } \\
\hline \multicolumn{7}{|c|}{ b. Dependent Variable: job satisfaction } \\
\hline
\end{tabular}

\begin{tabular}{|c|c|c|c|c|c|c|}
\hline \multicolumn{7}{|c|}{ Coefficients $^{\mathrm{a}}$} \\
\hline \multirow{2}{*}{\multicolumn{2}{|c|}{ Model }} & \multicolumn{2}{|c|}{ Unstandardized Coefficients } & \multirow{2}{*}{$\begin{array}{l}\text { Standardized Coefficients } \\
\text { Beta }\end{array}$} & \multirow[t]{2}{*}{$\mathbf{t}$} & \multirow[t]{2}{*}{ Sig. } \\
\hline & & B & Std. Error & & & \\
\hline \multirow[t]{5}{*}{1} & (Constant) & 78.294 & 1.281 & & 61.136 & .000 \\
\hline & Marital status & -13.032 & 1.014 & -.458 & -12.846 & .000 \\
\hline & Educational background & -.127 & .524 & -.009 & -.243 & .808 \\
\hline & Age & .066 & .775 & .004 & .085 & .932 \\
\hline & Gender & -17.466 & 1.264 & -.588 & -13.818 & .000 \\
\hline
\end{tabular}



Mubi.

The regression shows the relationship between the variables (marital status, educational background, age and gender) they are highly negative and positive as indicated by $\mathrm{R} 0.919(91.9 \%)$. The $\mathrm{R}^{2}$ statistic of $94.4 \%$ shows that the model is a good predictor of the dependant variables. This shows that the model explain about $90.5 \%$ variations in the dependant variable, while the remaining $9.5 \%$ is attributed to variables not captured by the regression model.

The examination of the contribution of individual variables in the model shows that the $\mathrm{t}$ - statistics is negative and positively signed $(-12.846,-0.243,0.085 \&$ -13.818) and it is statistically significant at 5\%. The F - statistics 351.129 also revealed that the variables of the model jointly explained the dependant variables. The significant value of $(\mathrm{P}<0.05)$ indicates that there is a positive and negative relationship between marital status, educational background, age, gender and job satisfaction.

\section{Findings}

The following findings were derived from the above data analysis;

i. Findings show that marital status have a significant effect on employee job satisfaction in ADSU, the result of the analysis further revealed that staffs are not satisfied with the content quality of their responsibility, finding further revealed that they don't have adequate technical support needed to carry out their duties diligently. In addition, the staffs also don't receive fair compensation and incentives for their role at the institution.

ii. Findings also revealed that employee educational background played a significant role in job satisfaction, those with higher qualification tend to be receiving higher salaries and more incentives, though the findings also revealed that the institution are not provided with necessary technology tools (i.e. equipment and software features) to enhance work. The result further revealed that employees are not satisfied with the convenience of the working environment.

iii. A finding further revealed that age groups of respondents has significant effect on the job satisfaction of employee, those between age bracket of 25-34 tend to be satisfied with their work compared to those of younger and older category of age. In addition, findings also show that staff training in ADSU didn't encourage staff relationship with their supervisors at work and staff didn't enjoyed their work because their organization don't usually encourage them to use their skills and talents better.

iv. Findings revealed that gender has significant effect on job satisfaction, male gender tend to be more satisfied with their work compare to female gender because they consider every work tedious and stressful. Furthermore, the finding also revealed that the institution doesn't usually offer opportunities for staff promotions, this affect the level of their job satisfaction.

\section{CONCLUSION AND RECOMMENDATIONS}

The paper concludes that marital status has a significant effect on employee job satisfaction in ADSU, staffs are not satisfied with the content quality of their responsibility, and staffs don't have adequate technical support needed to carry out their duties diligently. In addition, the staffs also don't receive fair compensation and incentives for their role at the institution.

Furthermore, the paper was able to conclude that employee educational background played a significant role in job satisfaction, those with higher qualification tend to be receiving higher salaries and more incentives, despite the fact that the institution are not provided with necessary technology tools (i.e. equipment and software features) to enhance work and 

Mubi.

most employees are not satisfied with the convenience of the working environment.

In addition, is observed that age groups of respondents have significant effect on the job satisfaction of employee, those between age bracket of $25-34$ tend to be satisfied with their work compared to those of younger and older category of age. The study further, concludes that staff training in ADSU didn't encourage staff relationship with their supervisors at work and staff didn't enjoyed their work because their organization don't usually encourage them to use their skills and talents better.

Lastly, the paper concludes that gender has significant effect on job satisfaction, male gender tends to be more satisfied with their work compare to female gender because the consider every work tedious and stressful. Also the institution doesn't usually offer opportunities for staff promotions, this affect the level of their job satisfaction.

\section{Recommendations}

From the above analysis, research findings and, the researcher was able to develop some recommendations:

i. The management should acknowledge the fact that women tend to spend less hours in their work compare to male counterpart, female are subjected to many natural factors that keep them away from work and they should be given due consideration for their absenteeism from work some times, the management should made to contents of responsibility given to staff to flexible not rigid, the management should also provide adequate technical support needed to carry out their duties diligently and staffs should also be given fair compensation and incentives for their role at the institution.

ii. It is also recommended that, management of ADSU should take notice of staff qualification before assigning them to a particular task, because education play a very vital role in staff job satisfaction, the management should also make available all the necessary technological tools (i.e. equipment and software features) to enhance work. The management should also provide offices with enough space that will make the working environment conducive for their staff.

iii. The management of ADSU Mubi need to understand that older people will not be satisfy with the content of their job because it will also be too tedious for them to perform as expected and this tend to affect the level of their job satisfaction, younger employees are likely to discharge their duties diligently because of that youthful age. Therefore, older people should be given due consideration whenever they failed to meet out with target. Also there is need for staff training and their supervisor should also be encouraging them to use their skills and talents better in the institution.

iv. The management should acknowledge the fact that gender also played a significant role in job satisfaction of employee, female should not be given work that is too tedious and stressful considering their nature. Also there is need for ADSU management to offer opportunities for staff promotions when due, this will go along way to increase staff job satisfaction.

\section{Acknowledgement: None}

\section{Conflict of Interest: None}

\section{Source of Funding: None}

\section{REFERENCES}

1. Amangala, T. A. (2013): The Effect of Demographic Characteristics on Organizational Commitment: A Study of Salespersons in the Soft Drink Industry in Nigeria. European Journal of Business and Management,5(4).

2. Armstrong $M$ (2006). A Handbook of Human Resource Management Practices. Tenth Edition, London: Kogan Page Publishing. 
3. Aziri, B., (2011). Job satisfaction: A Literature Review, Management Research and practice, 3(4) 77-86.

4. Bas, T., Ardic, K. (2002). A comparison of job satisfaction between public and private university academicians in Turkey. METU studies in Development, 29 (1-2): 27-46.

5. Bender, K. A., \& Heywoo, J. S. (2006). Job Satisfaction of the Highly Educated: The Role of Gender, Academic Tenure, and Earnings. Scottish Journal of Political Economy, 53(2), 253-279.

6. Beyene, T. \& Gituma, M. (2017). The influence of employee demographic factors on job satisfaction: A case study of Segen Construction Company, Eritrea. African Journal of Business Management, 11(29).

7. Blythe, J. (2005): Essentials of Marketing. Harlow, Essex, England: Pearson Education Limited.

8. Brewer, E. W, Lim, D. H. \& Cross, M. E. (2008). Job satisfaction and employee perception of the learning environment in the health care management industry. J. Leadership Stud. 1(4):37-50.

9. Cano, J., \& Miller, G., (1992). A gender analysis of job satisfaction, job satisfier factors and job dissatisfy factors of agricultural education teachers. Journal of Agricultural Education, 33(3), 40-46.

10. Castillo, J. X., \& Cano, J. (2004). Factors Explaining Job Satisfaction Among Faculty. Journal of Agricultural Education, 45(3), 72.

11. Cetin, M. O. (2006). The relationship between job satisfaction, occupational and organizational commitment of academics. Journal of American Academy of Business Cambridge, 8(1), 78-88.

12. Collins, B. A. \& Helen, K. A., (2013). Influence of demographic factors on job stress and job satisfaction among custom officials in Gana. Research in Humanities and Social Sciences, 13(16), 37- 44.

13. Crossman, A., \& Harris, P. (2006). Job satisfaction of secondary school teachers. Educational Management, Administration and Leadership, 34(1), 29-46.

14. DeVaney, S. A., \& Chen, Z. S. (2003). Job Satisfaction of recent graduates in Financial services, US Department of Labour. Bureau of Labour Statistics Compensation and Working Conditions Online.

15. Eyupoglu, S. Z., \& Saner, T. (2009). Job satisfaction: Does rank make a difference? .
African Journal of Business Management, 3(10), 609- 615.

16. Gurbuz, A. (2007). An assessment on the effect of education level on the job satisfaction from the tourism sector point of view. Dogus Universitesi Dergisi,, 8(1), 3646.

17. Hagedorn, L. (2000). What contributes to job satisfaction among faculty and staff. . New Directions for Institutional Research.

18. Hickson, C., \& Oshagbemi, T. (1999). The effect of age on the satisfaction of academics with teaching and research. International Journal of Social Economics, 26(4), 537-544.

19. Igalens J, Roussel P (1999). A French comparative study of the relationships between compensation work motivation and job satisfaction of exempt and non-exempt employees", Working Paper No. 224 (9624), LIRHE, Unicersite Toulouse I, Toulouse.

20. Khan, S.U.D., Nawaz, A. \& Jan, F. A. (2012). Impact of Demographic Diversities on the Job Satisfaction and Its Consequences: Case of Academicians in Higher Learning Institutions of Pakistan (Application of Stepwise Multiple Regression)

21. Lise, M.S., \& Timothy, A.J., (2004). Employee Attitudes and Job satisfaction, 43 (4) ,395-407.

22. Luthans, F. (2005). Organizational behavior. McGraw-Hills International Edition.

23. Malik, M.E., Nawab, S., Naeem, B., Danish, R.Q. (2010). Job Satisfaction and Organizational Commitment of University Teachers in Public Sector of Pakistan. International Journal of Business and Management, 5(6): 17-26.

24. Malik, N. (2011). Study of job satisfaction factors of faculty members at university of Baluchistan. International Journal of Academic Research, 3(1), 267-272.

25. Mcneely, R. L.,(1984). Occupation, gender and work satisfaction in a comprehensive human service department. Administration in Social Work, 8(2), 35-47.

26. Mehboob, F., Sarwar, M. A., \& Bhutto, N. A. (2012). Factors affecting job satisfaction among faculty member. Asian Journal of Business and Management Sciences, 1(12), 1-9. 
27. Miaris, M., (1996). Work satisfaction and gender. International Review of Modern Sociology, 26(1), 67-79.

28. Moguerou, P. (2002). Job satisfaction among US Ph.D. graduates: the effects of gender and employment sector. mimeo University de Bourgogne.

29. Naval, B. \& Srivastava, D. (2004). Sectorial Comparison of Factors Influencing Job Satisfaction in Indian Banking Sector. Singapore Management Review, 26(2):8999.

30. Oshagbemi, T. (2003). Personal correlates of job satisfaction: empirical evidence from UK universities. International Journal of Social Economics, 30(12), 1210-1232.

31. Paul, E. P., \& Phua, S. K. (2011). Lecturers' job satisfaction in a public tertiary institution in Singapore: ambivalent and non-ambivalent relationships between job satisfaction and demographic variables. Journal of Higher Education Policy and Management, 33(2), 141-151.

32. Sabharwal, M., \& Corley, E. A. (2009). Faculty job satisfaction across gender and discipline The Social Science Journal(46), 539-556.

33. Saiyadain, M. (1998). Correlates of job satisfaction among Malaysian managers. Malaysian institute of management Kuala Lampure. Malaysia.

34. Santhapparaj, A. S., \& Alam, S. S. (2005). Job satisfaction among academic staff in private universities in Malaysia. Journal of Social Sciences, 1(2), 72-76.

35. Sattar, A., Khan, S. \& Nawaz, A. (2010). Predicting JS of executive officers in NWFP, Pakistan. Gomal University Journal of Research. 12(3):45-61.
36. Shajahan, S. \& Shajahan, L. (2004). Organization behavior. New York.New Age International Publications

37. Soleman, H. A. B., (2005). Gender, ethnicity and job satisfaction among social workers in Israel. Administration in Social Worker, 29(3), 7-21.

38. Ssesanga, K., \& Garrett, R. (2005). Job satisfaction of University academics: Perspectives from Uganda. Higher Education, 50(1), 33-56.

39. Syed, A. A. S. G., Nadeem, B., Sabir, M., Faiz, M., Shaikh, \& Hina, S. (2012). Job Satisfaction of Faculty Members of Universities in Pakistan: A Case Study of University of Sindh-Jamshoro. Modern Applied Science, 6(7).

40. Warsi, S., Fatima, N., \& Sahibzada, A.S., (2009). Study on relationship between organizational commitment and its determinants among private sector employees of Pakistan. International Review of Business Research Paper, 5(3), 399-410.

41. Wikipedia (2009). Job satisfaction, Retrieved on $14^{\text {th }}$ July 2018 from: http://en.wikipedia.org/wiki/job_satisfaction

42. Yunki, K. (1999). The Determinants of Public Officials Job satisfaction - The case of Korean Public Officials in Cadastral Administration (pp 1-10), Chongju University Press.

How to cite this article: Bello S, Nasiru M. Demographic factors and its influence on job satisfaction in Adamawa State University, Mubi. International Journal of Research and Review. 2021; 8(5): 167-176. DOI: https://doi.org/10. 52403/ijrr.20210524 